Selcuk Journal of Agriculture and Food Sciences

http://sjafs.selcuk.edu.tr/sjafs/index

Research Article
SJAFS

(2020) 34 (2), 118-123

e-ISSN: 2458-8377

DOI:10.15316/SJAFS.2020.204

\title{
The Opinions and Expectations of the Farmers on Socio-Economic Impacts of Yortanlı Dam in Bergama District of Izmir Province
}

\author{
(DB Betül SUSAM SEREZ ${ }^{1,}$, (DSait ENGINDENIZ ${ }^{1^{*}}$ \\ ${ }^{1}$ Ege University, Faculty of Agriculture, Department of Agricultural Economics, İzmir, Turkey
}

\begin{tabular}{l}
\hline ARTICLE INFO \\
\hline Article history: \\
Received date: 19.03 .2020 \\
Accepted date: 04.05 .2020 \\
\hline Edited by: \\
Zuhal KARAKAYACI ; Selçuk Univer- \\
sity, Turkey \\
Reviewed by: \\
Altuğ ÖZDEN; Adnan Menderes Uni- \\
versity, Turkey \\
Murat MERCAN; Ege University, \\
Turkey
\end{tabular}

Keywords:

Agricultural irrigation

Land use

Rural development

Yortanlı dam

\begin{abstract}
The aim of this study is to determine opinions and expectations of the farmers on socio-economic impacts of Yortanlı dam in Bergama district. For this purpose, nine settlements of Bergama district that will benefit from dam irrigation were included. In this research, data were collected from 87 farmers with proportional sampling and by the survey. In the analysis of the data, firstly the socio-economic characteristics of the farmers were examined. Then, the opinions and expectations of the farmers about the socio-economic impacts of the dam in various aspects were determined. Five-point Likert scale was used in this stage. According to the results of the research, $72.41 \%$ of the farmers stated that the dam had positive impacts on agricultural production. $34.48 \%$ of the farmers think that the dam increases agricultural income. $85.06 \%$ of the farmers believe that agricultural lands are used more effectively after the dam. On the other hand, $65.52 \%$ of the farmers think that the dam will not reduce the migration from the region. However, $51.72 \%$ of the farmes stated that the dam will affect the young farmers positively. As a result, with the development of irrigation opportunities with the dam, income level and employment opportunities in the region may increase. Therefore, the young population in the region should be encouraged to agricultural production and private sector investments should be encouraged for processing agricultural products.
\end{abstract}

\section{Introduction}

Today, irrigated agriculture makes important contributions to maintaining food security and plays a critical role in world food production (Le Visage et al, 2018). There are 1.52 billion hectares of cultivated land in the world and $20.1 \%$ of this land is irrigated. $41.3 \%$ of the irrigated lands are located in China and India. Turkey has $1.7 \%$ of irrigated land in the world (FAO, 2018).

Too many dams have been built for agricultural irrigation in different countries of the world. Dams provide socio-economic and environmental benefits in rural areas. In countries with water problems, dams are needed for efficient use of water in terms of resource sustainability and economic development (Engindeniz et al., 2014). On the other hand, the positive and negative effects of dams can emerge over time. Therefore, scientific research in this direction should be done after each dam and the results should be evaluated. Generally, the effects of dams on agricultural production and income level, population and employment are emphasized. While the effects of irrigation dams on agricultural production and income levels are evaluated as

\footnotetext{
* Corresponding author email: sait.engindeniz@ege.edu.tr
}

direct effects, the effect on employment is considered as an indirect effect.

So far about the effects of dams in Turkey have been numerous studies. In some of these studies, the dams' environmental impacts (Gümüş et al., 2006; Yıldırım, 2006; Tahmişçioğlu et al., 2007; Satılmiş, 2009; Akkaya et al., 2009; Üslü, 2011; Sönmez, 2012; Özdemir, 2015; Yıldırımer et al., 2015; Doğan et al., 2016), the dams' impacts on climate (Emiroğlu et al., 1996; Yeşilnacar and Gülşen, 1999; Bulut et al., 2006; Şengün, 2007; Bacanlı et al., 2015; Kum, 2016), the dams' impacts on fishes (Özkurt, 2000; Kirankaya and Ekmekçi, 2007; Berkün et al., 2008), the dams' impacts on cultural assets (Sariyıldiz et al., 2008), and the dams' social and economic impacts have been analyzed (Sarıyıldız et al., 2005; Ulaş, 2008; Engindeniz et al., 2010; Tumer and Aksoy, 2011; Engindeniz et al., 2014, Baskaya and Turk, 2015; Kurt, 2015; Kocyigit and Emiroglu, 2016; Özbey, 2017; Akgün, 2018). However, the dams' impacts in different regions should also be evaluated in terms of farmers.

Yortanl1 Dam, the construction of which was completed in 2011 and opened to operation since 2013, is located $18 \mathrm{~km}$ the northeast of Bergama district center and on the Yortanl1 Stream. The dam is expected to provide agricultural irrigation in an area of 6,990 hec- 
tares. The aim of this study is to determine opinions and expectations of the farmers on socio-economic impacts of Yortanlı dam in Bergama district.

\section{Materials and Methods}

This research covers the farmers in nine settlements consisting of Alibeyli, Ayaskent, Aziziye, Bölcek,
Dagestan, Göçbeyli, Kadıköy, Sarıcalar and Zağnos located in the Yortanlı dam region (Figure 1). According to the data of Directorate of the Ministry of Agriculture and Forestry of Bergama District, the number of farmers registered in the Farmer Registration System in nine settlements is 842 (Table 1).



Figure 1

The location of the Yortanlı dam

Table 1

Distribution of farmers by settlements

\begin{tabular}{lccc}
\hline Settlements & $\begin{array}{c}\text { Total } \\
\text { number of } \\
\text { farmers }\end{array}$ & $\%$ & $\begin{array}{c}\text { Sample } \\
\text { size }\end{array}$ \\
\hline Alibeyli & 104 & 12.35 & 11 \\
Ayaskent & 125 & 14.85 & 13 \\
Aziziye & 34 & 4.04 & 3 \\
Bölcek & 141 & 16.75 & 14 \\
Dağıstan & 74 & 8.78 & 8 \\
Göçbeyli & 222 & 26.36 & 23 \\
Kadiköy & 84 & 9.98 & 9 \\
Sarıcalar & 40 & 4.75 & 4 \\
Zağnos & 18 & 2.14 & 2 \\
Total & 842 & 100.00 & 87 \\
\hline
\end{tabular}

In the research, it was decided that it would be appropriate to include of farmers with sampling and the following the proportional sampling formula was used (Newbold, 1995). This sampling method has been used in many previous studies (Özdemir et al., 2015, Tiryakioğlu and Artukoğlu, 2015; Çonoğlu et al., 2016; Kızıloğlu and Kızılaslan, 2017; Yüzbaşığlu, 2019; Bozdemir et al., 2019; Barlas et al., 2019).

The compost was produced by vertical silo method by the Kemerburgaz Organic Waste Compost Factory in Istanbul, which is one of a few compost producing organizations in Turkey. Relevant chemical properties of the compost are given in Table 2.

$$
n=\frac{N p(1-p)}{(N-1) \sigma_{p x}^{2}+p(1-p)}
$$

In formula;

$\mathrm{n}=$ Sample size
$\mathrm{N}=$ Total number of farmers

$\mathrm{p}=$ Proportion of farmers that cultivate irrigable land (based on 0.5)

$$
\sigma_{p x}^{2}=\text { Variance. }
$$

The calculations are based on a $95 \%$ confidence interval and a $10 \%$ error margin, and the sample size is 87. While determining the number of farmers to be surveyed in the settlement units, the calculation was made on the share of each settlement in the total number of farmers. Research data was collected in 2017.

In the analysis of the data, primarily the socioeconomic characteristics of the farmers were examined. Then, the opinions and expectations of the farmers regarding the socio-economic impacts of the dam were determined. At this stage, the five-point Likert scale was used.

In the conversion of the population in farms to the unit of male labor force (EIB); the coefficients of 0.50 for males and females in the 7-14 age group, 1.00 for males in the 15-49 age group, 0.75 for males in the 5064 age group, 0.50 for females were based on (Aras, 1988).

\section{Results and Discussion}

The socio-economic characteristics of the farmers are given in Table 2. The age of the farmers varies between 29-74, and the average age is 52.10. The average education period and agricultural experience of the farmers was determined as 8.18 years and as 14.31 years, respectively. 
Table 2

Socio-economic characteristics of farmers

\begin{tabular}{lc}
\hline Age of farmers & 52.10 \\
\hline Education periods of farmers (years) & 8.18 \\
Agricultural experience of farmers (year) & 14.31 \\
Household size (person) & 3.96 \\
Labor force potential of family (unit of male labor & 2.85 \\
force) & \\
Land size (decare) & 72.15 \\
Rate of equity capital (\%) & 62.08 \\
Rate of being a cooperative member (\%) & 98.85 \\
\hline
\end{tabular}

The household size of the farms is 3.96 person and $50.72 \%$ of them are male. The average family labor force potential in farms is 2.85 as a male labor unit (EIB) and 855 as a male labor day (EIG).

The average land size in the farms is 72.15 decares. The average number of parcels is 3.56 and the average parcel size is 20.27 decares. $49.70 \%$ of the lands in the farms are operated lands by the owner, $34.61 \%$ of the lands are rented land and $15.69 \%$ of the lands are operated lands by the partner. Cotton, wheat, corn and tomato are generally produced in the farms.

As an average of farms, $86.30 \%$ of total assets are land assets. When the distribution of the assets according to the items is examined; a large share of land assets (78.04\%), followed by tool-machine assets $(10.56 \%)$ and land reclamation $(6.49 \%)$ respectively. However, equity capital constitutes $62.08 \%$ of passive assets. 86 of 87 farmers included in the research are partners to at least one agricultural cooperative.

The farmers in the study were asked how their agricultural production was affected after the dam was completed. $72.41 \%$ of the farmers stated that the dam had positive affects (Table 3 ).

Table 3

The farmers' answers to the question "how did the completion of the dam affect your agricultural production?"

\begin{tabular}{lcc}
\hline Answers & Number of farmers & $\%$ \\
\hline Positively affected & 63 & 72.41 \\
Negatively affected & 0 & 0 \\
No affected & 8 & 9.20 \\
No idea & 16 & 18.39 \\
Total & 87 & 100.00 \\
\hline
\end{tabular}

Dams can positively affect agricultural lands and usage patterns, as well as increase the irrigation opportunities and increase production. These expectations were also revealed in the studies conducted before the Yortanlı Dam was put into operation (Sarıyıldız et al., 2005; Engindeniz et al., 2010).

It is expected that cotton production will continue in the region after the dam, whereas other products will be preferred by partially giving up wheat production. It is thought that the most important of the products that can be an alternative to wheat may be corn, and also tomato and cotton farming can be preferred.

When the farmers were asked how the agricultural income levels changed after the dam was completed; $34.48 \%$ of farmers stated that their agricultural income increased and $33.33 \%$ did not change (Table 4).

Table 4

The farmers' answers to the question "how did your agricultural income level change after the dam was completed?"

\begin{tabular}{lcc}
\hline Answers & Number of farmers & $\%$ \\
\hline My income increased & 30 & 34.48 \\
My income decreased & 1 & 1.15 \\
My income has not changed & 29 & 33.33 \\
No idea & 27 & 31.04 \\
Total & 87 & 100.00 \\
\hline
\end{tabular}

When the farmers' opinons and expectations on the effects in the region after the dam is completed are examined; it was determined that they agree with the expresions 'irrigation opportunities increased' (4.03), 'fly increased' (3.78), 'environmental pollution has occurred' (3.76), 'land became fragmented' (3.74), 'air quality deteriorated' (3.50), 'land prices and rents increased' (3.49), 'marketing opportunities improved' (3.05). On the other hand, they do not agree with the expressions 'employment opportunities increased' (2.78), 'roads are extended' (2.75), 'transportation opportunities improved' (2.52), 'local population increased' (2.44) (Table 5).

When the opinions of the farmers about the frequency of land sales in the region after the dam was completed, $49.42 \%$ stated that they had no idea, $25.29 \%$ increased of sales frequency and $25.29 \%$ it has not change (Table 6).

Table 5

The farmers' answers to the question "what level do you participate in the local effects after the dam is completed?"

\begin{tabular}{|c|c|c|c|c|c|c|c|c|c|c|c|}
\hline \multirow{2}{*}{ Effects of dam } & \multicolumn{2}{|c|}{$\begin{array}{c}\text { Strongly } \\
\text { disagree (1) }\end{array}$} & \multicolumn{2}{|c|}{$\begin{array}{l}\text { Disagree } \\
\text { (2) }\end{array}$} & \multicolumn{2}{|c|}{$\begin{array}{c}\text { Undecided } \\
\text { (3) }\end{array}$} & \multicolumn{2}{|c|}{ Agree (4) } & \multicolumn{2}{|c|}{$\begin{array}{l}\text { Strongly } \\
\text { agree (5) }\end{array}$} & \multirow[t]{2}{*}{ Mean } \\
\hline & $\mathrm{N}$ & $\%$ & $\mathrm{~N}$ & $\%$ & $\mathrm{~N}$ & $\%$ & $\mathrm{~N}$ & $\%$ & $\mathrm{~N}$ & $\%$ & \\
\hline Irrigation opportunities increased & 0 & 0 & 0 & 0 & 1 & 1.15 & 82 & 94.25 & 4 & 4.60 & 4.03 \\
\hline Fly increased & 0 & 0 & 6 & 6.90 & 12 & 13.79 & 64 & 73.56 & 5 & 5.75 & 3.78 \\
\hline Environmental pollution has occurred & 0 & 0 & 9 & 10.34 & 9 & 10.34 & 63 & 72.42 & 6 & 6.90 & 3.76 \\
\hline Land became fragmented & 0 & 0 & 10 & 11.49 & 8 & 9.20 & 64 & 73.56 & 5 & 5.75 & 3.74 \\
\hline Air quality deteriorated & 0 & 0 & 21 & 24.14 & 8 & 9.20 & 51 & 58.62 & 7 & 8.04 & 3.50 \\
\hline Land prices and rents increased & 1 & 1.15 & 17 & 19.54 & 13 & 14.94 & 50 & 57.47 & 6 & 6.90 & 3.49 \\
\hline Marketing opportunities improved & 0 & 0 & 33 & 37.93 & 20 & 22.99 & 31 & 35.63 & 3 & 3.45 & 3.05 \\
\hline Employment opportunities increased & 0 & 0 & 47 & 54.02 & 14 & 16.09 & 24 & 27.59 & 2 & 2.30 & 2.78 \\
\hline The roads are extended & 0 & 0 & 43 & 49.42 & 24 & 27.59 & 19 & 21.84 & 1 & 1.15 & 2.75 \\
\hline Transportation opportunities improved & 0 & 0 & 61 & 70.11 & 8 & 9.20 & 17 & 19.54 & 1 & 1.15 & 2.52 \\
\hline Local population increased & 1 & 1.15 & 64 & 73.56 & 6 & 6.90 & 15 & 17.24 & 1 & 1.15 & 2.44 \\
\hline
\end{tabular}


Table 6

The farmers' answers to the question "has the number of land sold after the dam completed?"

\begin{tabular}{lcc}
\hline Answers & Number of farmers & $\%$ \\
\hline Sales frequency increased & 22 & 25.29 \\
Sales frequency decreased & 0 & 0 \\
It has not changed & 22 & 25.29 \\
No idea & 43 & 49.42 \\
Total & 87 & 100.00 \\
\hline
\end{tabular}

$41.38 \%$ of the farmers within the scope of the research stated that after the dam was completed, they had no idea about the change of land prices, $29.88 \%$ of the land prices did not change and $28.74 \%$ of the prices increased (Table 7).

When the farmers were asked whether the lands sold after the dam was completed were used for agricultural purposes, they all answered yes.

Table 7

The farmers' answers to the question "has the land purchase-sale prices changed after the dam was completed?"

\begin{tabular}{lcc}
\hline Answers & Number of farmers & $\%$ \\
\hline Prices increased & 25 & 28.74 \\
Prices not changed & 26 & 29.88 \\
No idea & 36 & 41.38 \\
Total & 87 & 100.00 \\
\hline
\end{tabular}

$85.06 \%$ of the farmers evaluated the dam in their region positively in terms of effective use of agricultural lands (Table 8).

When farmers were asked whether the dam would reduce migration in the region, $65.52 \%$ gave no reduce answer (Table 9).

In previous studies conducted in different regions, it has been revealed that dams cannot reduce migration (Tümer and Aksoy, 2011; Koçyiğit and Emiroğlu, 2016).

Table 8

The farmers' answers to the question "how do you evaluate the dam in your region area in terms of effective use of agricultural lands?"

\begin{tabular}{lcc}
\hline Answers & Number of farmers & $\%$ \\
\hline Positive & 74 & 85.06 \\
Negative & 0 & 0 \\
No idea & 13 & 14.94 \\
Total & 87 & 100.00 \\
\hline
\end{tabular}

Table 9

The farmers' answers to the question "does the dam in your region reduce migration?"

\begin{tabular}{lcc}
\hline Answers & Number of farmers & $\%$ \\
\hline Reduce & 8 & 9.19 \\
Not reduce & 57 & 65.52 \\
No idea & 22 & 25.29 \\
Total & 87 & 100.00 \\
\hline
\end{tabular}

When asked how the dam would affect younger farmers, it stated that it could affect $51.72 \%$ positively (Table 10).
Table 10

The farmers' answers to the question "how does a dam in your region affect the young farmers?"

\begin{tabular}{lcc}
\hline Answers & Number of farmers & $\%$ \\
\hline Positive & 45 & 51.72 \\
Negative & 0 & 0 \\
No effect & 31 & 35.63 \\
No idea & 11 & 12.65 \\
Total & 87 & 100.00 \\
\hline
\end{tabular}

According to the research results, the farmers believe that the dam is beneficial for the effective use of the local lands. They express that their agricultural production is positively affected by the increase of irrigation opportunities. However, they also emphasize that the dam may have some environmental and physical adverse effects.

With the development of irrigation opportunities with the dam, it is expected that the income level and employment opportunities in the region may increase, therefore, the population may continue to live in the region and consequently migration will decrease. Apart from this, it is estimated that there may be a population flow by immigration to the region from other regions. However, although some of the farmers within the scope of the research think that immigration will not decrease, they believe that the dam can positively affect young people. It is necessary to encourage the young population in the region to agricultural production and to encourage private sector investments in the processing of agricultural products.

After the dam is completed, it is expected that the corn will have the most important share in the product pattern in the region and that the tomato will follow. However, while determining the product pattern, farmers should also conduct market researches and make the most of the supports provided.

As a conclusion, dams provide socio-economic and environmental benefits in rural areas. However, the positive and negative effects of dams can emerge over time. Therefore, scientific research in this direction should be conducted after each dam and the results should be evaluated.

\section{Acknowledgements}

We would like to thank the Ege University Scientific Research Projects Commission which provided financial support for the project No 16-ZRF-020 and the local farmers who patiently responded to the survey questions.

\section{References}

Akgün Ç (2018). Cost Analysis of Environmental Impacts for Tuzluca Dam. Master Thesis, Institute of Science and Technology of Gümüşhane University, Gümüşhane.

Akkaya U, Gültekin AB, Dikmen ÇB, Durmuş G (2009). The Analysis of Environmental Impacts of 
Dams and Hydroelectric Power Plants (HEPP): Sample of Ilisu Dam. 5th International Advanced Technologies Symposium, 13-15 May, 2009, Karabük.

Aras A (1988). Agricultural Accounting. Publication of Faculty of Agriculture of Ege University, No:486, Izmir.

Bacanlı ÜG, Tuğrul AT (2015). A climate impact of dam lake and Recep Yazıcı̆ğlu Gökpınar dam lake sample. Pamukkale University Journal of Engineering Sciences 22(3):154-159.

Barlas S, Örmeci Kart, MÇ, Kınıklı F, Işın Ş (2019). Factors affecting the production decisions of cut flowers producers in Menderes Region of Izmir province. Atatürk University Journal of the Agricutural Faculty 50(3): 231-238. (in Turkish)

Berkün M, Aras E, Koç T (2008). Effects of dams and hydroelectric power plants on river ecology. Turkey Engineering News 452:41-48.

Bozdemir M, Bayramoğlu Z, Ağızan K, Ağızan S (2019). Prudential expectation analysis in maize production. Turkish Journal of Agriculture - Food Science and Technology 7(3):390-400.

Bulut H, Yeşilata B, Yeşilnacar İ (2006). Deterination of the Impact of Atatürk Dam Lake on Regional Climate by Trend Analysis. Proceedings of the Fifth GAP Engineering Congress, 26-28 April, 2006, Şanliurfa, p.79-86.

Çonoğlu S, Kaynak T, Demirbaş N, Tosun N (2016). Tendencies of farmers to soil analysis subsidy: a case study of Izmir province. Ege Journal of Agricultural Research 53(4):441-449.

Doğan E, Çeribaşı G, Akkaya U (2016). Investigation for effecting of dam to river flow regime by trend analysis method: case study of Sakarya River. Karaelmas Science and Engineering Journal 6(1):50-55.

Emiroğlu ME, Özkan F, Öztürk M (1996). A Research on the Impact of Keban Dam Reservoir on Climate Conditions of Elazig Province. Proceedings of First GAP Engineering Congress, 29 May 1996, Şanlıurfa, p.167-174.

Engindeniz S, Atış E, Saner G (2010). The Effects of Yortanl 1 Dam on the Socio-Economic Structure of the Region. Yediveren Printing House, Izmir.

Engindeniz S, Atış E, Saner G, Coşar, G (2014). Irrigation Dams in terms of Sustainability of Agriculture and Farmers' Expectations: Yortanl1 Dam. 11th National Agricultural Economics Congress, 3-5 September, 2014, Samsun, p.54-63.

FAO (2018). Agricultural statistics, http://faostat.fao.org, Access: December 2018.

Gümüş B, Dalkılıç N, Toprak F (2006). Versatile Evaluation of Ilisu Dam and HEPP. Ilisu Dam and HEPP Research Commission Report, Dicle University Faculty of Engineering and Architecture, Diyarbakir.
Kırankaya ŞG, Ekmekçi FG (2007). Variations in growth properties of chub (squalius cephalus, l., 1758) living in Gelingüllü Dam Lake. Journal of Ballkesir University Institute of Science and Technology 9(2): 125-134.

Kızıloğlu R, Kızılaslan N (2017). Fertilizer use the condition of cultivator province center in Kahramanmaras. Turkish Journal of Agriculture Food Science and Technology 5(1): 18-23.

Koçyiğit N, Emiroğlu A (2016). An analysis of productive potential of ermenek reservoir formation and its impact on the reasons of socio-economic condition and migration of the regional population, Academic Journal of History and Idea 3(10):90-107.

Kum G (2016). The influence of dams on surrounding climate: the case of Keban Dam. Gaziantep University Journal of Social Sciences 15(1):193-204.

Kurt E (2015). Problems within Dam Expropriation: Kayseri Gümüşören Dam Case. Master Thesis, Institute of Science and Technology of Aksaray University, Aksaray.

Le Visage S, Kuper M, Venot JP, Yercan M, Atış E (2018). Pursuing the state's hydraulic mission in a context of private groundwater use in the Izmir Province, Turkey. Water Alternatives 11(2): 421438.

Newbold P (1995). Statistics for Business and Economics. Prentice Hall International Editions.

Özdemir B, Akbay C, Çelik A (2015). The current status and problems of apple growers in Gülnar District of Mersin City. Turkish Journal of Scientific Reviews 8 (2): 56-58.

Özdemir HY (2015). Determination of Land Use Change in Hasanlar Dam Basin. Master Thesis, Institute of Science and Technology of Düzce University, Düzce.

Özkurt Ş (2000). Boron accumulation in carp tissues (Cyprinus carpio l., 1758) in Dam Lakes Çötören and Kunduzlar (Kırka-Eskişehir). Turkish Journal of Biology 24 (2000): 663-676.

Sarıyıldız A, Atış İ, Tomar A (2005). The evaluation of the Bakırçay Kınık project Yortanlı and Çaltıkoru dams in terms of local economy and social effects and some facts. Journal of Izmir Commodity Exchange, October.

Sarıyıldız A, Tahmiscioğlu S, Silay A, Tomar A (2008). Investigation of the Conservation of Cultural Heritage Approaches in the Development of Water Resources in the Example of Yortanlı Dam. The Union of Chambers of Turkish Engineers and Architects 2nd Water Policy Congress, 20-22 March, 2008, Ankara, p. 541-554.

Satılmış M (2009). Environmental Impact Assessment of Dams and Hydroelectric Power Plants. Forum2009, Eastern Black Sea Region Hydroelectric Energy Potential and Its Place in Country Energy Policies, 13-15 November, 2009, Trabzon, p.151-154. 
Sönmez ME (2012). The negative impacts of dams on environment and their samples in Turkey. Gaziantep University Journal of Social Sciences 11 (1) : $213-231$.

Şengün MT (2007). The effect of Keban Dam on Elazig climate in the light of recent evaluations. Journal of East Anatolian Region Research 5:116121.

Tahmişçioğlu MS, Anul N, Ekmekçi F, Durmuş N (2007). Positive and Negative Impacts of Dams on the Environment. International Congress on River Basin Management, 22-24 March, 2007, AntalyaTurkey, pp:759-769.

Tiryakioğlu M, Artukoğlu MM (2015). A research on table olive production, marketing, problems and solutions: the case of Akhisar. Ege Journal of Agricultural Research 52(2):131-139.

Tümer Eİ, Aksoy A (2011). Attitudes towards construction of the Laleli Dam and socio-economical characteristics of the farmers in Laleli Basin. Atatürk University Journal of Agricultural Faculty 42(1): 41-47.

Ulaş H (2013). Irrigation Cost of Irrigable Agricultural Areas: The Case of Adıyaman Çamgazi Dam. Mas- ter Thesis, Institute of Social Sciences oF Hasan Kalyoncu University, Gaziantep.

Üslü A (2011). Environmental Impact Cost Analysis of Ilisu Dam. Master Thesis, Institute of Science and Technology of Karadeniz Technical University, Trabzon.

Yeşilnacar Mİ, Gülşen H (1999). Climatic Characteristics of Şanliurfa and the Surrounding Region and the Effects of Atatürk Dam Lake on Regional Climate. Proceedings of the 52nd Geological Congress of Turkey, 10-12 May, 1999, Ankara, p.122-128.

Yildırım A (2006). Karakaya Dams and effects of naturel environment. Journal of Ziya Gökalp Education Faculty of Dicle University 6:32-39.

Yıldırımer S, Özalp M, Erdoğan Yüksel E (2015). Determining loss and degradation of lands as a result of large dam projects and associated road constructions within the Coruh River Watershed. Artvin Coruh University Journal of Forestry Faculty 16(1):1-17.

Yüzbaşığlu R (2019). Tendencies of rural producer to soil analysis province center in Tokat. Journal of Bahri Dagdas Crop Research 8(1): 163-169. 